\title{
Mandenkan
}

MANDENIKAN Bulletin semestriel d'études linguistiques mandé

$56 \mid 2016$

Numéro 56

\section{Manding reflexive verb constructions and registers in Jula of Burkina Faso}

Les constructions réfléchies mandingues et les registres en dioula de Burkina Faso

РЕФЛЕКСИВНЫЕ КОНСТРУКЦИИ И СТИЛИСТИЧЕСКИЕ РЕГИСТРЫ В ДЬЮЛА

БУРКИНА ФАСО

Coleman Donaldson

\section{OpenEdition}

\section{Journals}

Electronic version

URL: https://journals.openedition.org/mandenkan/894

DOI: $10.4000 /$ mandenkan.894

ISSN: 2104-371X

\section{Publisher}

Llacan UMR 8135 CNRS/Inalco

\section{Printed version}

Date of publication: 1 December 2016

Number of pages: 3-28

ISSN: 0752-5443

\section{Electronic reference}

Coleman Donaldson, "Manding reflexive verb constructions and registers in Jula of Burkina Faso", Mandenkan [Online], 56 | 2016, Online since 16 February 2017, connection on 08 July 2021. URL: http:// journals.openedition.org/mandenkan/894 ; DOI: https://doi.org/10.4000/mandenkan.894

This text was automatically generated on 8 July 2021.

\section{(c) (i) (ㅇ)}

Les contenus de Mandenkan sont mis à disposition selon les termes de la Licence Creative Commons Attribution - Pas d'Utilisation Commerciale - Partage dans les Mêmes Conditions 4.0 International. 


\section{Manding reflexive verb constructions and registers in Jula of Burkina Faso}

Les constructions réfléchies mandingues et les registres en dioula de Burkina

Faso

РЕФЛЕКСИВНЫЕ КОНСТРУКЦИИ И СТИЛИСТИЧЕСКИЕ РЕГИСТРЫ В ДЬЮЛА

БУРКИНА ФАСО

Coleman Donaldson

1 Manding is a language and dialect continuum stretching across West Africa from Senegal to Burkina Faso (BF). The Manding lingua franca Jula is often considered to be either a Bamanan-inspired L2 or "the spoken Manding of non-Mandings" (Dumestre \& Retord 1981:3; Mansour 1993). Jula, as spoken in Côte d'Ivoire, has attracted substantially more formal linguistic attention than in Burkina Faso (Braconnier, Maire \& Tera 1983; Dumestre \& Retord 1981; Dumestre 1970; Dumestre 1974; Partmann 1973; Sangaré 1984). Increasingly, however, Burkinabè linguists (e.g., Keita 1990; Sanogo 2013) have suggested that a prestigious urban identity associated with the western city of Bobo-Dioulasso has led to the emergence of Burkina Faso Jula (BFJ) as a distinct, relatively stable Manding variety for an entire generation of Burkinabè.

Despite these developments, there has been little recent fieldwork dedicated to the formal differences between Jula and other Manding varieties. As such one goal in this paper is to explore one structural way in which Jula seems to differ from other Manding varieties: the forgoing of formally reflexive constructions in favor of formally ambiguous intransitive constructions and more rarely innovative idiomatic transitive constructions. To do so, I draw on contextually elicited forms from 2012 fieldwork with 9 BFJ speakers in Burkina Faso.

3 The most recent work focusing on BFJ's formal features (Sanogo 2013: 263-264) seems to suggest that what makes BFJ finally worthy of formal analysis is that it now has native speakers. While this is certainly not a negligible factor in its evolution, 
investigating the forms of $\mathrm{BFJ}$ also presents an opportunity to probe at the language boundaries of the Manding world (Bazin 1985; Canut 2002; Van den Avenne 2015a), which - like much of Africa (Irvine \& Gal 2000; Errington 2008; Blommaert 2013; Irvine 2008) - has been primarily determined by "departmentalized Linguistics" (Agha 2007a) and the Saussurean division between LANGUE and PAROLE that brackets off speakers' own rationalization and interpretations of language in use. In this paper therefore, I embrace Jula's vehicular nature and opt to preliminarily explore the range of possible reflexive constructions across isomorphic boundaries through grammaticality/acceptability judgments and METAPRAGMATIC commentary (Silverstein 1976) as well as field data and textual artifacts ${ }^{1}$ collected in 2012. The research question and subquestions guiding this inquiry can thus be seen as the following:

How are reflexive verbs used by speakers of Jula in Burkina Faso?

a. Is there a prototypically BFJ construction?

b. What other constructions are used and how?

\section{Conceptual framework}

\subsection{Manding \& linguistic differentiation in Africa}

4 A language and dialect continuum stretching across much of West Africa, the word Manding itself is an adaptation derived from the word Màndén ${ }^{2}$, the name for the former West African polity now commonly referred to as the Mali Empire that reigned over much of the area between the 13th and 15th century (Simonis 2010; Levtzion 1973). In this sense, all of the Manding varieties can be viewed as the heritage of this Màndén Empire. The glottonym of BFJ, jùlakán, literally 'Jula/trader's language', stems historically from the Manding lexeme jùlá meaning 'trader', which refers to the Muslim itinerant traders associated with the Mandén empire (Sanogo 2003; Sanogo 2013; Wilks 1968; Wilks 2000). Manding varieties that are frequently treated as languages (i.e., Maninka in Guinea, Bamanan in Mali, and Jula in Côte d'Ivoire and BF), are widely used in their respective zones as trade languages between different peoples and language groups (Dalby 1971). While linguists clearly acknowledge their connectedness and overlap (Creissels 2009; Dumestre 2003), national language policies and linguistic work typically treat them largely as distinct though related languages or varieties.

These boundaries between Manding varieties and peoples as in much of Africa stem in large part from the founding ideologies of linguistics as a discipline (Irvine \& Gal 2000: 76). Embedded in the descriptions and classifications of African languages by European outsiders is "an assumption of normative monolingualism" that stems from the sociolinguistic regimes of the linguistic investigators' home societies. In the case of Manding peoples and languages, linguistic divisions arose from the French colonial linguist Delafosse's linguistic classification method for distinguishing ethnic groups which ignored the bilingualism inherent in parole to focus on an idealized vision of one langue per person based on speakers use of glottonyms (Bazin 1985). More recently, modern dialectologists have attempted to overcome the artificial borders inherent in this model by conceptualizing Manding varieties as part of an indistinguishable continuum: 
[Manding] is a linguistic continuum with linguistic distance between its extreme representatives slightly overpassing the limit of mutual intelligibility of around 90 common words in the 100-word list of Swadesh. There are no clear-cut limits within this continuum, so the traditionally distinguished languages (or dialects) "Bambara, Malinke, Dioula"3, etc. are in fact subcontinua smoothly flowing into each other (Vydrin 1995a: 2).

This vision, while useful, makes it difficult to take into account lingua francas or vehicular varieties that permit communication across what linguistics has identified as isomorphic borders. As Irvine and Gal (2000:77) demonstrate, these functional varieties, such as BFJ, are typically rendered invisible by ideologies of monolingualism and linguistic homogeneity.

7 The recent scholarly attention that BFJ has drawn has been linked to its emergence as a regionally recognized variety with native speakers (Sanogo 2013: 263-264). Despite this, Sanogo (2003: 377) recognizes that what he labels as "vehicular Jula" is in fact the nexus of:

- various 'ethnic Jula' varieties stemming from pre-colonial dialects of Jula traders that settled in the region;

- a new urban first language variety;

- a less stable commercial Jula used between speakers of disparate languages.

8 Thus while Sanogo (2013) elaborates upon some of the distinguishing features of BFJ, he nonetheless suggests that they are not definitive; frequently in the course of accommodation while communicating it is not possible to distinguish which Manding variety a BFJ speaker is speaking (274). Indeed for anyone that speaks another Manding variety, Jula "is not really a second language but rather a second way of speaking" (Dumestre \& Retord 1981: 3).

9 My own sense of Manding variation and speech practices is informed by my two years working and traveling in West Africa as a Peace Corps Volunteer based in Jula-speaking Burkina Faso between 2009 and 2011. Every day in my rural village without running water, paved roads or electricity, I was exposed to a multilingualism at least as, if not more, cosmopolitan than that of Brussels. While I worked with civil servants in French, I dedicated my free time to learning Jula, which functioned as a lingua franca between the many ethnic groups that lived in the area. Thus a typical day was punctuated by translanguaging (García, 2009) between and across upwards of five languages a day: Cerma, Jula, Mooré, French and Fulani amongst others.

10 Aware of my interest in Jula, Burkinabè friends regularly declared that if I truly wanted to learn Jula, I would somehow mysteriously have to learn Bamanan. Others insisted that what I was learning was not in fact "true Jula" (jùlakán' yèreyere) but "street Jula" (siraba' ká jùlakán). Strangely though, I found that if I attempted to play off of these distinctions, my jokes would frequently fall flat. For instance, while traveling in Mali when I was asked incredulously, "é bé bámanankan' mén? ('You speak Bambara?') and responded ón-Jn, ń bé jùlakán' lè fó ('No, I speak Jula'), I normally faced nothing but incomprehension or a quick lesson: ù béc kélen! ('They're all the same!').

11 Despite this, Bamanan is nonetheless often viewed as more prestigious or indeed as the 'true' form of the language. As Dumestre \& Retord (1981:3) note in the introduction to their Jula of Côte d'Ivoire learner's manual:

The limit between Jula and Maninka from a sociolinguistic point of view is rather clear: the image of the Jula language, by and large, is negative; that of Maninka is not, that of Bamanan or any other [Manding] variety of the land is not. (my translation) 

that citizens no longer view $\mathrm{BFJ}$ as an impoverished Manding variety but rather embrace it as a sign of urban Burkinabè identity. In my own experience from my Peace Corps service (2009-2011) and fieldwork in 2012, 2013 and 2016, BFJ is certainly recognized and used as a legitimate de facto standard register across the Southwest of the country. This nonetheless does not prevent speakers from also viewing other forms as particularly prestigious. Many ethnic Jula friends to this day regularly insist that to truly learn Jula I must head to Kong in Côte d'Ivoire, while others suggest that I should simply go to Mali and learn Bamanan.

d'Ivoire, they do not to tell us for whom and under what conditions Jula, as a 'way of speaking' (Whorf 1956; Hymes 1974), is negatively or positively viewed. Answering such questions requires attending to language's "reflexive" character (Lucy 1993; Agha 2007b) or the fact that people are constantly engaged in talk about talk. Whether implicitly or overtly, speakers continually "refer to and predicate about language in use" (Wortham 2001: 71). Silverstein (1976) denotes this as "metapragmatic" language use, or what Rymes (2014) succinctly labels "metacommentary".

14 Focusing on metapragmatic comments and usage allows us to incorporate speakers' own rationalizatons about speech into our models of linguistic boundaries and variation. This approach is central to a "linguistics of contact" that does not reify the "linguistic utopia" of a homogenous speech community into ever smaller subcommunities (Pratt 1987). From this perspective, investigating lingua francas such as Jula through metacommentary is useful for how we can explore "the operation of language ACRoss lines of social differentiation" (Pratt 1987: 60). In fact, it is in these arguably richer (in terms of different linguistic and cultural forms coming together) zones of contact that we can likely more fully explore how linguistic forms become ENREGISTERED (Agha 2007b) into the dialects and sociolects of linguistics through their association with certain kinds of social classifications. To do this, we must attend to "the system of social relations embedded in the denotational norms of a language" (Agha 2007b: 143) through a sociologically informed account of REGISTERS.

\subsection{Registers}

15 While registers are typically conceived of as different ways of speaking a language, Agha (2007b) defines them as 'cultural models of action' identifiable by: features or REPERTOIRE CHARACTERISTICS; enactable values or a SOCIALRANGE; and a set of users or a SOCial DOMAIN (Agha 2007b, 169). Moreover, registers must be understood as being simply snapshots of socio-historical processes of ENREGISTERMENT "whereby diverse behavioral signs [...] are functionally reanalyzed as cultural models of action" (Agha 2007b, 55). Critically, this conceptualization allows us to account for the social value of functional language varieties such as BFJ which have typically been absent from linguistic analysis. By functional varieties I am referring to forms of spoken language that seem to mix grammatical codes as typically defined as separate by linguists. While distinct grammatical systems certainly can be identified and their mixing in use can eventually lead to new languages, the fact remains that in the social world linguistically-defined grammatical codes can and do seep across registers (Frekko 2009; Mcintosh 2010). 

anthropologists following the work of Peirce (1992). While Saussure (1972) theorized one kind of sign made up of a signifier and a signified in establishing his vision of linguistics, Peirce distinguishes three kinds of signs: symbols, icons and indices (Mertz 1985). A Peircean symbol parallels Saussure's basic sign and serves well to describe the semantic machinery or denotational coding feature of language. An index, on the other hand, is a sign that has a value that can only be established in context. Indexicality therefore refers to the notion of a pointing-to relationship or "contextual connection" (3). For my purposes here however I will focus on the level of SOCIAL INDEXICALS, that is, the features and their arrangement in interaction from which we infer information about kinds of people and activities (Agha 2007b). isomorphic boundaries, I identified one distinct grammatical feature to focus on: reflexive verb constructions. For the purposes of this paper, I use REFLEXIVE VERB to refer to semantically reflexive verbs that are prototypically used in syntactically reflexive constructions in Bamanan (Vydrine 1994; Vydrine 1995b). This does not mean that these semantically "reflexive verbs" are typically used as syntactically reflexives constructions in Jula. In BFJ there are essentially three possible types of reflexive verb constructions. First, in contradistinction to the formally reflexive construction of Bamanan (Dumestre 2003) and Maninka (Creissels 2009), prototypically in BFJ, semantically reflexive verbs tend to be used intransitively. Secondly, in the case of certain semantically true reflexive verbs, Jula speakers may also use idiomatic transitive constructions. Nonetheless, acceptability judgments reveal a final option; syntactically reflexive constructions that are prototypically Bamanan are also possible in BFJ. As part of this preliminary analysis of the social domain and social indexicality of these seemingly divergent forms I draw upon the metapragmatic commentary of my consultants as well as field notes and artifacts.

\section{Reflexive verbs in Burkina Faso Jula}

First, let us look at basic Manding syntax and formal reflexive constructions as classically understood through the lens of Bamanan.

\subsection{Basic Manding syntax}

19 Basic Manding syntax is S (O) V with an auxiliary (or PREDICATIVE MARKER in the Mande linguistics tradition) appearing in the post-subject position (examples (1) through (6) are standard Bamanan):

\begin{tabular}{|l|l|l|l|l|}
\hline$(1)$ & $A$ & $b \varepsilon ́$ & dén- & kò. \\
\hline & $3 S G$ & IPFV.AFF & child-ART & wash \\
\hline & \multicolumn{3}{|l}{ 'He washes the child'. } \\
\hline
\end{tabular}




\begin{tabular}{|l|l|l|l|l|}
\hline$(2)$ & A & má & táa & \\
\hline & 3SG & PFV.NEG & go & wash \\
\hline \multicolumn{4}{|l}{ He didn't go. } \\
\hline
\end{tabular}

The one exception is for affirmative intransitive sentences where the perfective marker appears as a suffix -ra/-la/-na of the verb:

\begin{tabular}{|l|l|l|}
\hline$(3)$ & A & táa-ra. \\
\hline & 3SG & go-PFV.INTR \\
\hline & 'He went'. \\
\hline
\end{tabular}

\subsection{Formal reflexives}

21 Manding reflexive constructions typically parallel transitive constructions with overt objects in that the reflexive pronoun occurs in direct object position:

\begin{tabular}{|l|l|l|l|l|l|l|}
\hline (4) & a. & Ń & yé & ń & kò. & 'I washed myself. (litt. 'I washed me') \\
\hline & & ISG & PFV.AFF & 1SG & wash & \\
\hline & b. & I & $y^{\prime}$ & í & kò. & 'You (sg.) washed yourself'. \\
\hline & c. & Án & $y^{\prime}$ & án & kò. & 'We washed ourselves'. \\
\hline
\end{tabular}

In (4b) and (4c) note that $y$ 'is the typical orthographic convention for marking the phonological assimilation of the vowel that takes places when an auxiliary is followed by a vowel-initial pronouns or reflexive markers: Án yé i $i$ fo $\rightarrow$ án y'i fo [án yí î fo] 'We greeted you'.

23 The reflexive pronoun is typically identical to the subject pronoun for all except third person singular ${ }^{4}$ which often appears as $i$ as opposed to $\grave{a}$ :

\begin{tabular}{|l|l|l|l|l|}
\hline$(5)$ & A & $y^{\prime}$ & i & kò. \\
\hline & $3 S G$ & PFV.AFF & REFL & wash \\
\hline \multicolumn{4}{|c}{ 'He washed himself'. } \\
\hline
\end{tabular}

Nonetheless in some varieties, the third person singular $\grave{a}$ can be used in place of the reflexive pronoun: 


\begin{tabular}{|l|l|l|l|l|}
\hline (6) & A & $y^{\prime}$ & $\grave{a}$ & kò. \\
\hline & 3SG & PFV.AFF & $3 S G$ & wash \\
\hline \multicolumn{4}{|l}{ 'He washed himself. } \\
\hline
\end{tabular}

In both of these cases, as demonstrated in (5) and (6), there is potential referential ambiguity. First, as seen in (4), the second person singular pronoun is $i$ and therefore identical to the reflexive pronoun $i$. Second, as seen in (6), there is ambiguity as to whether $a$ refers to the subject of the sentence (e.g., 's/he washed him/herself) or to some other antecedent (e.g. 'S/he washed it/him/her').

This potential referential ambiguity can be resolved by the use of the intensifying modifier yغ̀r ('self', cf. French: même) and the third person singular ’̀:

\begin{tabular}{|c|c|c|c|c|c|c|}
\hline (7) & a. & A & $y^{\prime}$ & $\grave{a}$ & $y \grave{\varepsilon} r \varepsilon$ & kò. \\
\hline & & $3 S G$ & PFV.AFF & REFL & self & wash \\
\hline \multicolumn{7}{|c|}{ 'He washed himself'. } \\
\hline & & He & hed it & elf'. & & \\
\hline
\end{tabular}

\begin{tabular}{|c|c|c|c|c|c|}
\hline b. & À & $y^{\prime}$ & î́ & yદ̀rદ & kò. \\
\hline & $3 S G$ & PFV.AFF & REFL & self & wash \\
\hline \multicolumn{6}{|c|}{ 'He washed himself', } \\
\hline & & & & & \\
\hline
\end{tabular}

\subsection{Burkina Faso Jula reflexives}

SEMANTIC REFLEXIVITY in general refers to the notion that the agent and patient of a given action are one and the same. Thus in an expression such as "He shaved", the verb "shave" is reflexive because by omitting a direct object, the sentence is necessarily interpreted as one of the agent shaving himself. Verbs in this sense can be SEMANTICALLY REFLEXIVE regardless of their argument structure (e.g., transitive or intransitive).

FORMAL REFLEXIVITY on the other hand is determined by purely morpho-syntactic criteria; that is, in the case of Manding, whether the verb is used in a transitive construction that repeats the subject pronoun or uses the formal reflexive marker $i \hat{i}$ as in examples (4) through (7). This is the typical means used to identify so-called REFLEXIVE VERBS (RV) in Bamanan.

In BFJ however verbs identified as RVs in Bamanan are most often used intransitively. Other researchers note that formally reflexive and intransitive constructions are also 
possible in some varieties of Bamanan (Creissels 2007; Koné 1984; Vydrine 1994; Vydrine 1995b). This absence of formal reflexivity in BFJ however extends even to verbs such as kó 'wash' that are semantically defined as TRUE REFLEXIVEs (i.e., where the agent acts literally upon themselves). In these cases, the clause is often semantically ambiguous between active and passive voice:

\begin{tabular}{|l|l|l|}
\hline$(8)$ & A & kò-ra. \\
\hline & 3SG & wash-PFV.AFF \\
\hline & 'He bathed'. \& 'He was washed (by someone)'. \\
\hline
\end{tabular}

More uniquely, in BFJ constructions with semantically true RVs are replaced by innovative idiomatic transitive constructions that are judged nonsensical in Bamanan and other Manding varieties:

\begin{tabular}{|l|l|l|l|l|l|}
\hline (9) & a. & A & yé & ji-' & kò. \\
\hline & & 3SG & PFV.AFF & water-ART & wash \\
\hline & & 'He bathed', litt. 'He washed water'. \\
\hline
\end{tabular}

The RV constructions that can be used in BFJ can be summarized as follows:

Table 1. RV construction types

\begin{tabular}{|c|c|c|c|c|c|c|c|c|}
\hline & Type & Construction & \multicolumn{2}{|c|}{ Example } & & & & Gloss \\
\hline 1 & \multirow{2}{*}{$\begin{array}{l}\text { Formally } \\
\text { Reflexive }\end{array}$} & í & $\begin{array}{l}A \\
3 S\end{array}$ & $\begin{array}{l}y^{\prime} \\
\text { PFV.AFF }\end{array}$ & $\begin{array}{l}\hat{i} \\
\text { REFL }\end{array}$ & \multicolumn{2}{|c|}{$\begin{array}{l}\text { kò. } \\
\text { wash }\end{array}$} & $\begin{array}{l}\text { 'He bathed'.\& } \\
\text { 'He washed you } \\
\text { (sg.)'. }\end{array}$ \\
\hline 2 & & à & $\begin{array}{l}A \\
3 S G\end{array}$ & $\begin{array}{l}y \\
\text { PFV.AFF }\end{array}$ & $\begin{array}{l}\grave{a} \\
3 S G\end{array}$ & \multicolumn{2}{|c|}{$\begin{array}{l}\text { kò. } \\
\text { wash }\end{array}$} & $\begin{array}{l}\text { 'He bathed' \& } \\
\text { 'He washed it'. }\end{array}$ \\
\hline 3 & $\begin{array}{l}\text { Complex } \\
\text { Reflexive }\end{array}$ & à yèrદ & $\begin{array}{l}A \\
3 S G\end{array}$ & $\begin{array}{l}y^{\prime} \\
\text { PFV.AFF }\end{array}$ & $\begin{array}{l}\grave{a} \\
\text { REFL }\end{array}$ & $\begin{array}{l}y \grave{\varepsilon} r \varepsilon \\
\text { self }\end{array}$ & $\begin{array}{l}\text { kò. } \\
\text { wash }\end{array}$ & 'He washed himself'. \\
\hline 4 & Intransitive & IV & $\begin{array}{l}A \\
3 S G\end{array}$ & $\begin{array}{l}\text { kò-ra. } \\
\text { wash- } \\
\text { PFV.AFF }\end{array}$ & & & & $\begin{array}{l}\text { 'He bathed'. \& } \\
\text { 'He was washed'. }\end{array}$ \\
\hline
\end{tabular}




\begin{tabular}{|l|l|l|l|l|l|l|l|}
\hline 5 & Idiom & TV & $\begin{array}{l}\text { A } \\
\text { 3SG }\end{array}$ & $\begin{array}{l}\text { yé } \\
\text { PFV.AFF }\end{array}$ & $\begin{array}{l}\text { ji } \\
\text { water }\end{array}$ & $\begin{array}{l}\text { kò. } \\
\text { wash }\end{array}$ & 'He bathed'. \\
\hline
\end{tabular}

32 Having outlined Manding RV syntax as typically understood through Bamanan, as well as BFJ's less explored RV constructions, let us move onto to the actual data and analysis.

\section{Methods}

To guide my inquiry, I used Vydrine's (1994; 1995b; 2011) sorting of Bamanan RVs into various semantic classes. In particular, I focused on verbs from the following classes: TRUE and AUTO-CAUSATIVE.

True RVs denote the notion of the agent literally acting upon themselves as an object (Vydrine 1995b: 21). Prototypical examples include those such as mùn 'coat, cover' or kò 'wash'. Auto-causative RVs denote the notion of the agent displacing themself ${ }^{5}$ or changing their bodily position voluntarily (1995b: 39). Vydrine lists examples such as bilá 'put', múnumunu 'turn around' etc.

Table 2. RV semantic classes

\begin{tabular}{|l|l|l|l|}
\hline & RV Class & Definition & Bamanan example \\
\hline 1 & True & agent literally acts upon themself & A y’i nógo. ‘He dirtied himself. \\
\hline 2 & Auto-Caus. & agent voluntarily displaces themself & Č̌ ‘ y’i dá. ‘The man laid down'. \\
\hline
\end{tabular}

From across these classes, I selected 10 RVs identified in Vydrine's (1994) article that I recognized as present in BFJ and used them to collect RV constructions judged by 9 different BFJ speakers from across the country.

Data was elicited via the following methods. Using my own network of contacts, I identified individuals I knew to be Jula speakers and then asked if they would be willing to participate in my study. If they agreed, I produced my notebook and took down basic notes on their age, self-reported verbal repertoire and place of origin. While in this article I will not rely heavily on this information, it is summarized below:

Table 3. Selected information on research participants

\begin{tabular}{|l|l|l|l|l|l|}
\hline & $\begin{array}{l}\text { Birth } \\
\text { year }\end{array}$ & Where grew up & $\begin{array}{l}\text { When learned } \\
\text { Jula }\end{array}$ & Other languages & Ethnicity \\
\hline 1 & 1954 & $18 \mathrm{~km}$ from Niger & Adult & Mooré, Gourma, English & Gourmantché \\
\hline 2 & 1984 & $\begin{array}{l}23 \mathrm{~km} \mathrm{from} \mathrm{Bobo-} \\
\text { Dioulasso }\end{array}$ & Child & "lúkan" (Bobo-Madare?) & Bobo-Madare \\
\hline 3 & 1987 & Bobo-Dioulasso & Child & French & Turka \\
\hline
\end{tabular}




\begin{tabular}{|l|l|l|l|l|l|}
\hline 4 & 1989 & Bobo-Dioulasso & Child & French & Samo \\
\hline 5 & 1956 & Kona & Child & $?$ & Marka-Dafin \\
\hline 6 & 1975 & Ouagadougou & $\begin{array}{l}\text { Child (at school in } \\
\text { Dédougou) }\end{array}$ & Bobo-Madare & Senoufo \\
\hline 7 & 1967 & Soubakaniédougou & Child & Cerma, French & Jula \\
\hline 8 & 1981 & Soubakaniédougou & Child & $\begin{array}{l}\text { Samogo, Cerma, French, } \\
\text { English, Senoufo }\end{array}$ & Samogo \\
\hline 9 & 1988 & Soubakaniédougou & Child & French & Jula \\
\hline
\end{tabular}

Having collected their responses, I subsequently elicited grammaticality judgments by producing a hypothetical story and then asking them what they did subsequently in response (e.g., Question: "You played soccer and got all sweaty last night, so what did you do?" Response: "I bathed."). Next, I asked them to use this same verb while referring to a hypothetical third person (e.g., Question: "How would you say it if we were talking about someone else?" Response: "He bathed.") I used both French and BFJ in my queries depending on my comfort and relationship with the speaker. I noted down their response for each verb and any commentary regarding grammaticality or incertitude. Subsequently, having completed the 10-verb list, I returned to their responses and asked them what it would mean if one produced the same utterance albeit with one of the other possible RV constructions (cf. Table 1) which I produced myself.

Elicitations were conducted in Ouagadougou, Bobo-Dioulasso and Soubakaniédougou at the participants' home or place of work. In terms of any influence that I may have had, my only sense is that participants were potentially more likely to produce casual lingua franca forms because the Jula that I myself typically spoke and used with all of them was often regarded as "street Jula" (siraba' ká jùlakán). Given that I myself have heard the range of syntactic forms investigated here, I do not believe that speakers were unduly influenced to accept forms as possible or grammatical out of context.

\section{Varieties or registers?}

\subsection{Prototypical Jula Reflexives}

As demonstrated in Table 4, it is apparent that at least in the case of the verbs selected, they are prototypically realized intransitively in BF. Through my elicitations I obtained fifty-four intransitive construction tokens out of sixty-eight possible reflexive constructions.

Table 4: Construction preference tokens for 10 reflexive verbs from 9 speakers

\begin{tabular}{|l|l|l|l|l|l|}
\hline & \multicolumn{4}{|l|}{ Construction } \\
\hline Verbs by Class & TV & IV & î̀ & à yère & à \\
\hline
\end{tabular}




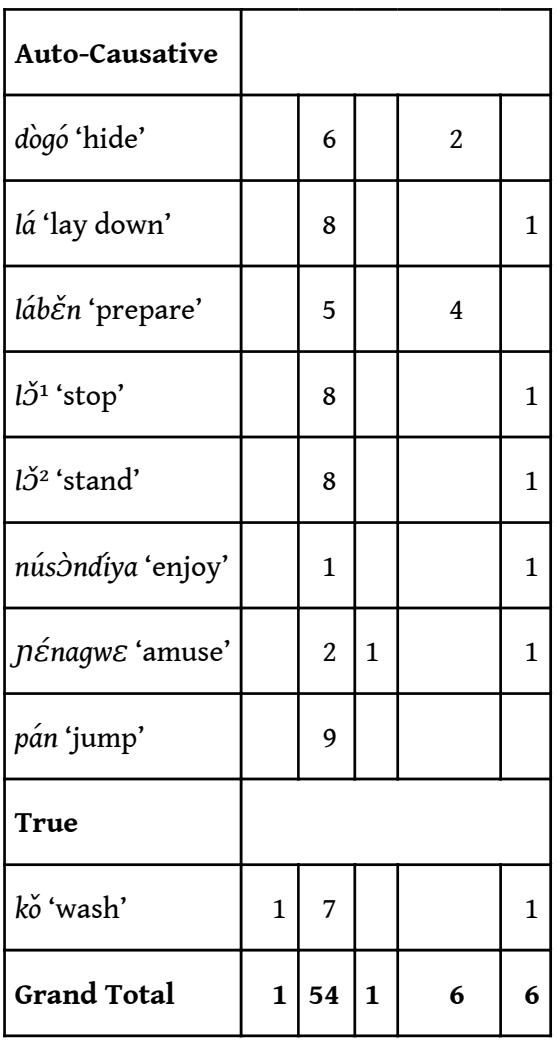

It therefore seems that BFJ's prototypical construction for these RVs is intransitive and not formally reflexive as in Bamanan or Maninka. This feature of Jula is confirmed by BF's lexicographic tradition, which provides overt commentary on which syntactic constructions are most "Jula". In the most recent officially produced Jula lexicon produced in Burkina Faso (1995) verbs are listed alphabetically preceded by an infinitive marker kà or k'à which refer to intransitive and transitive constructions respectively whereas we would expect $k^{\prime} i$ if it was formally reflexive (p.148, my translation):

$$
\begin{aligned}
& \text { kà lá 'lay oneself down' } \\
& \text { k'à lá 'lay down; put into a pile' }
\end{aligned}
$$

41 This format for reflexive verbs in an official lexicon overtly typifies BFJ as having prototypically intransitive syntax in the case of RVs. Indeed, this format is preserved for all of the verbs under investigation except for núsòndiya, which does not appear as a verb, and nénagwe, which is simply absent as a lexeme.

These patterns of usage also hold across my participants regardless of the age at which they acquired Jula and in general across ethnicity (siya). Note that one's ethnicity is not indicative of mother-tongue. Both the Samo participant and the Turka participant for instance were from Bobo-Dioulasso and each reported to be bilingual in only Jula and French despite the variation in their preferred forms. In terms of the divergence of the Marka-Dafin participant, it is unclear to what extent any competence in Marka-Dafin may have influenced his responses because I failed to collect information on his first language. Given his background (grew up in Kona, learned Jula "in the streets"), it would be interesting to compare Marka-Dafin reflexives with those of BFJ. 
Table 5. RV construction preference by period of learning Jula and ethnicity

\begin{tabular}{|c|c|c|c|c|c|}
\hline \multirow[b]{2}{*}{ Ethnicity by learning age } & \multicolumn{5}{|c|}{ Construction } \\
\hline & à & à yèr & $\mathrm{i}$ & VI & VT \\
\hline \multicolumn{6}{|l|}{ Adult } \\
\hline Gurma & & & & 7 & \\
\hline \multicolumn{6}{|l|}{ Child } \\
\hline Bobo-Madare & & & & 7 & \\
\hline Jula & & 1 & & 13 & 1 \\
\hline Marka-Dafin & 4 & 2 & & 1 & \\
\hline Samo & 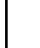 & 1 & & 6 & \\
\hline Samogo & . & & & 8 & \\
\hline Turka & 2 & 2 & & 5 & \\
\hline \multicolumn{6}{|l|}{ School } \\
\hline Senufo & & & 1 & 7 & \\
\hline Grand Total & 6 & 6 & 1 & 54 & 1 \\
\hline
\end{tabular}

\subsection{Registers across varieties}

While my elicited 'next turn' responses and the BF lexicographic tradition confirm these reflexive verbs as being used prototypically as intransitive, relying strictly on these sources only tells half of the story. Table 3 reveals that intransitive constructions which are ambiguous are the preferred or default Jula use of reflexive verbs. Categorizing Jula as being limited to strictly intransitive constructions however is wrong. Table 6 displays acceptability judgments for formally reflexive constructions that I elicited following the originally elicited responses of Table 4.

Table 6. Acceptability judgments for formally reflexive í constructions

\begin{tabular}{|l|l|l|l|}
\hline & \multicolumn{3}{|c|}{$i$ Construction Acceptability Judgments } \\
\hline Verbs by Class & Ungrammatical & Grammatical & Unsure \\
\hline Auto-Causative & & & \\
\hline dògó 'hide' & & 3 & \\
\hline
\end{tabular}




\begin{tabular}{|c|c|c|c|}
\hline lá ‘lay down' & & 4 & 1 \\
\hline lábc̀n 'prepare' & & 4 & \\
\hline lò' 'stop' & & 5 & \\
\hline lò' 'stand' & & 5 & \\
\hline núsòndiya 'enjoy' & 2 & 2 & \\
\hline jénagwe 'amuse' & 2 & 3 & \\
\hline pán 'jump’ & & 5 & \\
\hline True & & & \\
\hline kǒ 'wash' & 1 & 3 & \\
\hline Grand Total & 5 & 34 & 1 \\
\hline
\end{tabular}

In the elicited response of Table 4, there was only one instance of a reflexive verb being elicited in a formally reflexive $i$ construction. In Table 6 however we see that in followup queries those consultants that I asked judged alternative reflexive constructions grammatical 34 times with only 6 instances of judgments of hesitance or ungrammaticality. A more traditional analysis might stop here and view these acceptability judgments as resulting from the prestige of Bamanan and chalk it up to a limited view of Bamanan-Jula diglossia (Ferguson 1959) in which BFJ speakers can recognize but do not produce Bamanan.

But even my cursory archival research turned up instances of BFJ texts using formally reflexive or prototypically Bamanan forms. In 1998, the National Literacy Institute of Burkina Faso (la Direction Générale de l'Institut de l'Alphabétisation) published a small collection of folk tales (Traoré 1998). In the very first tale about the trials and tribulations of the animals of the forest we have examples such as the following (p. 3):

\begin{tabular}{|l|l|l|l|l|l|l|}
\hline$(9)$ & Loon & 0 & loon & sani & dugugwe & $c \varepsilon$ \\
\hline & day & DISTR & day & before & daybreak & between \\
\hline \multicolumn{7}{|l}{ 'Everyday before daybreak } \\
\hline
\end{tabular}

\begin{tabular}{|l|l|l|l|l|l|l|}
\hline$\ldots$ & sonsannin & $b \varepsilon$ & $\underline{\text { tag'i }}$ & $\underline{\min }$, & $\underline{k^{\prime} i}$ & $\underline{\text { ko... }}$ \\
\hline & hare & IPVF.AFF & go'REFL & drink & INF'REFL & wash \\
\hline \multicolumn{7}{|l}{ the hare goes and drinks and washes himself... } \\
\hline
\end{tabular}

Both of the underlined segments are formally reflexive constructions. Paradoxically from a typical linguistic point of view, this appears in a document ostensibly prepared 
by the same institution that three years prior produced an official Jula lexicon (1995) that listed Jula reflexives as intransitive. To be sure, this is not an instance of a Bamanan text labeled Jula; phonologically the rest of the excerpt is prototypically Jula in using forms such as lón 'day' and dùgugwé 'daybreak' as opposed to dón and dùgujé as one would expect respectively in Bamanan.

As such, I parsed Traoré's (1998) text for all occurrences of the following verbs in instances in which they could ostensibly appear in reflexive constructions: kò 'wash'; lá 'lay down'; lábèn 'prepare'; pán 'jump'; lò 'stand'. In addition, I did the same for three other BFJ texts; one bilingual folktale (Konaté 2010), one collection of folktales (An ka menni $k \varepsilon$ cekorobaw $f \varepsilon, n . d$.$) and finally one adult literacy text meant for mothers$ (1998). The statistics regarding these verbs in the texts is outlined in Table 7 below:

Table 7: RV constructions for four verbs (kò, lá, láben, pán) by BFJ text

\begin{tabular}{|c|c|c|c|c|c|}
\hline \multirow[b]{2}{*}{ Book } & \multicolumn{4}{|c|}{ Construction } & \multirow[b]{2}{*}{ Grand Total } \\
\hline & TV & $y \varepsilon \grave{r} r \varepsilon$ & $i$ & IV & \\
\hline$N$ deen... & & & & 2 & 2 \\
\hline Konaté, 2010 & & & 6 & & 6 \\
\hline An ka menni ke... & 1 & & 1 & 5 & 7 \\
\hline Traoré, 1998 & & 2 & 3 & 4 & 9 \\
\hline Grand Total & 1 & 2 & 10 & 11 & 24 \\
\hline
\end{tabular}

While this sample can by no means be regarded as an exhaustive corpus for BFJ, it clearly demonstrates the variable use of RV construction types. Both An ka menni kE... and Traoré (1998) use a range of constructions types while $N$ deen... and Konaté (2010) default to the IV-construction and $i$-construction respectively. A more detailed look at the construction types by verb across the texts, as in Table 8 below, suggests that the variability cannot be explained by the verb itself.

Table 8: RV constructions by verb across BFJ texts

\begin{tabular}{|l|c|c|c|c|c|}
\hline & \multicolumn{3}{|c|}{ Construction } & \\
\hline & TV & yère & í & IV & Grand Total \\
\hline lá 'lay down' & & & 1 & 1 & 2 \\
\hline lábèn 'prepare' & & 2 & & & 2 \\
\hline kò 'wash' & 1 & & 1 & 2 & 4 \\
\hline pán 'jump' & & & 2 & 4 & 6 \\
\hline
\end{tabular}




\begin{tabular}{|l|l|l|l|l|l|}
\hline lò 'stand' & & & 6 & 4 & 10 \\
\hline Grand Total & 1 & 2 & 10 & 11 & 24 \\
\hline
\end{tabular}
(Corpus Bambara de Référence, 2016), I made a series of formal queries which I then manually parsed to track the usage of construction types with the verb ko 'wash' when semantically reflexive. As outlined below in Table 9 , this investigation suggests that the protypical Bamanan construction for semantically reflexive verbs is indeed $\hat{i}+\mathrm{RV}$. Nonetheless, the corpus did turn up three total hits of ko being used either intransitively or in the idiomatic transitive expression kà ji' kò.

Table 9: Reflexive verb constructions with the verb kò in the disambiguated Bamanan corpus

\begin{tabular}{|c|c|c|}
\hline Construction & Forms & Reflexive Hits \\
\hline VI & bé kò; kòra; té kò & 1 \\
\hline VT & jík kò & 2 \\
\hline yદેrદ & yère kò & 2 \\
\hline à & à kò & 7 \\
\hline î & î kò & 25 \\
\hline Grand Total & & 37 \\
\hline
\end{tabular}

Thus even in a finite corpus of written Bamanan we see that, just as Jula-speakers do not only use and accept reflexive verbs in intransitive constructions, neither do Bamanan-speakers only accept and use syntactically reflexive constructions. While one single token of an intransitive construction is quite marginal, it is in itself interesting given that the authors discussed above explicitly make reference to it as a common 
dialectal variation. The question therefore remains as to what these distinct constructions may index in use and why the transitive and intransitive constructions do not pattern more robustly in the written texts of the corpus.

\subsection{Dialect to register. sociolinguistic high-forms} to my consultants' metapragmatic commentary. Formally reflexive constructions as in (5) were interpreted by Jula speakers in diverse ways.

54 are in line of those typically offered by linguists who primarily approach variation through the lens of language being tied to a place in the form of dialects ${ }^{7}$. Other participants however when queried about the divergence in forms typified formally reflexive forms as related to "church-speak; formality; heaviness; age" or even being "purely Manding." And for others it was simply ungrammatical.

These diverging metapragmatic stereotypes and grammaticality judgments demonstrate how registers have distinct social domains. For some Jula speakers, it is not a register that they have access to and it is therefore susceptible to judgments of ungrammaticality in decontextualized queries. For others, Bamanan is simply a Manding variety, distinct from Jula, which is spoken by Malians or Bamanan people. But this identification of Bamanan syntax as being an emblem of speaker kind is susceptible to further typification or SECOND ORDER REANALYSIS (Silverstein 2003). Indeed, for some Jula speakers metapragmatic commentary about formality or purity reveals that Bamanan-sounding speech has been enregistered as linked to things like church, formality etc. While a full account of the processes which gave rise to these metapragmatic stereotypes is beyond the scope of this article, the comments can be made sense of given some socio-historical context.

The fact that formal reflexive forms are associated with "formality", "heaviness" and "age" is not surprising given the fact that Jula often functions and is considered as an urban lingua franca that shows evidence of "simplification" (Partmann 1973; 1974). The grammatical forms most often used in city settings therefore become associated with other social phenomena that go along with places like Bobo-Dioulasso: youth, loss of customs, the informality of the marketplace etc. (for similar African cases see McLaughlin 2001; Spitulnik 1998). Formal reflexives thereby are not just tied to particular places, but rather to different social models of behavior that go along with notions of "age" or "heaviness".

The typification of formal reflexives as related to church-speak or being purely Manding on the other hand indexes perhaps more specific social processes. It is in part connected to the idea that Jula itself is derived from Bamanan. Explorers, missionaries, colonial agents and linguists began to produce both anglophone and francophone scholarship on Manding starting in the 19th century. Many of these early works focused in particular on Bamanan as part of an effort to facilitate French colonial conquest into the interior of West Africa (Van den Avenne 2015a; 2015b). Later, during and in the lead-up to World War I, the French colonial authorities relied to a large extent on Bamanan to facilitate communication between 208,000 African troops from across French West Africa (Afrique-Occidentale française) as well with their French superior officers (Van den Avenne 2005). The view of Bamanan as a sociolinguistic 
high-form of Manding today therefore is deeply connected to this history of colonial vehicularization.

Inextricable from this is the parallel and oftentimes intertwined work of Catholic missionaries who also published some of the earliest documents in and on Bamanan. Competing groups of missionaries set up shop in the Manding-speaking parts of the French Sudan, prior to military conquest, just before the turn of the century. Just two years after establishing a mission in Ségou, the first White Father's Bamanan grammar was produced in 1897 (Van den Avenne 2015a: 16). The mission of Bobo-Dioulasso on the other hand was not established until 1927, though it was staffed by at least one missionary, Father Ferrage, who had served in Kita (now Mali) for twenty-one years (1906-1927) and published a French-Bamanan manual for the tirailleurs sénégalais of the colonial army (16-17). The fact then that more Bamanan-like syntax use with RVs is read as church-like is therefore potentially unsurprising.

While I have not conducted exhaustive research in this regard, I can attest to the presence of more Bamanan-like forms in Catholic church documents that circulate in Southwestern Burkina Faso today. In 2010 for example I collected a printed leaflet with song lyrics distributed during a ceremony to inaugurate a new Catholic parish in Burkina Faso. This textual artifact includes basic titles in French listing the different segments of the liturgy (e.g., "Procession", "Entrée", "Kyrie" etc.) followed by song lyrics in Jula or Cerma ${ }^{8}$. However, the linguistic forms of the Jula sections demonstrate both the church's historical proselytization in Bamanan and the way that Bamanan and Jula are intertwined registers. For instance, the document includes forms that clearly are more Bamanan-like as underlined in third column of Table 10 below $^{9}$. To the right in the fourth column, I provide the typical BFJ equivalent.

Table 10: Excerpts of Church Jula in Catholic liturgy leaflet

\begin{tabular}{|c|c|c|c|}
\hline Section & $\#$ & Excerpt & BFJ form \\
\hline \multicolumn{4}{|l|}{ Entrée } \\
\hline & $(10)$ & O de ye ala sago ye 'That is God's wish' & lè FOC \\
\hline & $(11)$ & Ala i ni ce 'Thank you, God' & $\grave{a} 3 S G$ \\
\hline \multicolumn{4}{|l|}{ Gloria } \\
\hline & $(12)$ & Donkili ka $\underline{\mathrm{da}}, \mathrm{o} \mathrm{ka} \underline{\mathrm{da}}$ 'Songs shall be sung, they shall be sung' & lá ‘lay’ \\
\hline & $(13)$ & An be barika da i ye 'We lay praise before you' & lá ‘lay’ \\
\hline & $(14)$ & An b'i deli 'We beseech you' & dári 'beseech' \\
\hline \multicolumn{4}{|l|}{ Graduel } \\
\hline & $(15)$ & $\begin{array}{l}\text { Ne ba ye deen soro loon min na 'The day which my mother had a } \\
\text { child..'. }\end{array}$ & $\begin{array}{l}\text { bámuso } \\
\text { 'mother' }\end{array}$ \\
\hline Agnus Dei & & & \\
\hline
\end{tabular}




\begin{tabular}{|l|l|l|l|}
\hline & $(16)$ & $\begin{array}{l}\text { Faa ni den ka ben kelen ma 'May the father and child agree as } \\
\text { one' }\end{array}$ & fack 'father' \\
\hline $\begin{array}{l}\text { Action } \\
\text { Grâce }\end{array}$ & & & \\
\hline & (17) & $\begin{array}{l}\text { Ni ala m'i dèmè faso ti jo 'If God doesn't help you, the homeland } \\
\text { won't prosper' }\end{array}$ & lò 'erect' \\
\hline
\end{tabular}

At the same time however the leaflet is clearly not just a document borrowed from a Bamanan-speaking region; the document also includes evidence of being clearly written by or for a Jula speaker. For instance, the text includes excerpts employing some of the very same words outlined above but in their prototypical Jula form:

\begin{tabular}{|l|l|l|l|l|l|l|}
\hline$(18)$ & $<$ Ala & ya & togo & $\underline{\text { la }}$ & $\mathrm{e}$ & kan> \\
\hline & Ala & y'a & tógo-' & lá & $\hat{e}$ & kàn \\
\hline & God & PFV.AFF'3SG & name-ART & lay & 2SG.EMPH & on \\
\hline \multicolumn{7}{|l}{} \\
\hline
\end{tabular}

61 Here the author clearly uses the Jula form lá 'lay' as opposed to the Bamanan dá. In other cases, such as (19), single sentences appear to be hybrid in terms of their adoption of Bamanan or Jula conventions:

\begin{tabular}{|l|l|l|l|l|l|l|l|l|}
\hline$(19)$ & $<\mathrm{Ne}$ & ba & ye & deen & soro & loon & min & na> \\
\hline & Nê & bá' & yé & dén-' & sòro & lón & mîn & ná \\
\hline & 1SG.EMPH & mother & PFV.AFF & child-ART & obtain & day & REL & on \\
\hline \multicolumn{7}{|l}{ 'On the day which my mother had a child'. } \\
\hline
\end{tabular}

In this instance, the author's lexical choice of bá 'mother' eschews the typical BFJ form of bámuso. On the other hand, (19) utilizes the Burkinabè Jula orthographic convention of doubling the vowel of monosyllabic words (e.g., <deen> and <loon>) as well as the clear Jula form lón 'day' over the prototypical Bamanan dón. In short, historical work and textual artifacts of today align with my research participant's metapragmatic comment that more Bamanan-like reflexive verb syntax recalls church activity.

The remark that formal reflexive constructions are "purely Manding" on the other hand seems to gesture towards a different conceptualization of normativity. While Jula is undoubtedly a Manding language, this instance reveals that different grammatical configurations are interpretable as being more Manding than others. Interesting in this regard is the fact that the participant does not label the construction as purely Jula or Bamanan, but rather Manding. Given that the label Manding (mandingue or mànden-) 
does not circulate widely in everyday discourse in Burkina Faso, this usage here points to a particular trajectory of socialization into the idea that both Jula and Bamanan, despite occurring more readily as emic categories, are both subtypes of an overarching Manding-ness.

Whether relating to "age", "church" or "Manding(-ness)", it is important to see however that Jula speakers do not simply associate Bamanan forms and constructions with these kinds of indexical values. They also utilize and deploy them as a sociolinguistic high-form that is reflexively analyzed as "potentially indexical of speaker's relation to, or stance on, persons copresent" (Agha 2007b: 315). That is, their use, depending on the semiotic co-text, may be construed as either deferring to one's interlocutor or troping on the status of Bamanan syntax to diverse social effects.

Indeed, during my Peace Corps service such an instance was spontaneously produced during a market interaction between my friend, Sambo (S), a seller and a potential client (C) that I recorded on April 5, 2011 ${ }^{10}$ :

\begin{tabular}{|c|c|c|c|}
\hline & & Transcription & Translation \\
\hline 1 & $\mathrm{~S}$ & $\begin{array}{l}\text { Elè, ń bé síran î já sinon ń ká Jǐ kà marché } \\
\text { sòro dén kème ní bî dúuru mais n’i ly’à yé }\end{array}$ & $\begin{array}{l}\text { You, I'm afraid of you, cause I'm supposed to } \\
\text { make a profit, } 150 \text { units, but if you [have seen }\end{array}$ \\
\hline 2 & C & [(É yé séere $), n$ yé [sǒn yé? & [(You, you're the witness) and I'm [a thief? \\
\hline 3 & S & [Non, î jǒ tèn, ń bénà [kǒn k’à fó î yé & [No, stop, I'm gonna [tell you first! \\
\hline 4 & C & [Non, c'est vrai, moi, je n'aime [pas ça & [No, it's true, I don't like [that. \\
\hline 5 & $S$ & $\begin{array}{l}\text { [Non, je vais te dire ça gwé parce que je veux pas } \\
\text { dire ça à quelqu'un d'autre }\end{array}$ & $\begin{array}{l}\text { [No, I'm gonna say this real clear, because I } \\
\text { don't want to say it to anybody else. }\end{array}$ \\
\hline
\end{tabular}

Note how in the bolded segment of line 3 Sambo uses the Bamanan form i jò tèn 'Stop (like that)'. This happens despite the fact that he had never traveled to Mali in his entire life and that I regularly heard him use Jula form kà lò 'stop'. In fact, I did not even notice his use of both prototypically Bamanan syntax (that is, $i$ lì instead of simply lì as an imperative for 'Stop!') or Bamanan phonology (that is, $i$ jò instead of 'i lj) until much later when analyzing the transcript for Jula-French code-switching. I would argue here that this is evidence of the ways that register phenomena transcend the boundaries of the dialectologist. Jula and Bamanan are not simply dialects spoken in specific places within the Manding language and dialect continuum; they are also types of behavior that are associated with certain kinds of people and activities. As such, Manding forms and constructions travel and are utilized in social life as registers in ways that suggest there are alternative ways of approaching and mapping the language that can enrichen the models that linguists have constructed.

\section{Conclusion}

67 In this paper, I have tried to contribute to our understanding of the Manding lingua franca of Burkina Faso Jula. Confirming preliminary insights from Sanogo (2013) we 
have seen that indeed BFJ distinguishes itself formally from other Manding varieties in its use of reflexive verbs which, in fact, are prototypically used intransitively. Nonetheless, going beyond researcher elicitation of grammatical forms by collecting acceptability judgments and analyzing text artifacts reveals that BFJ speakers frequently recognize and in fact use reflexive constructions typically attributed to other Manding varieties such as Bamanan. This finding contributes to further refining the boundaries setup between Manding varieties by purely linguistic analysis. To go beyond simply deconstructing these boundaries however, I have attempted to preliminarily explore how Manding speakers use the different forms to do different kinds of work. To do this, I explored metapragmatic commentary from consultants regarding reflexive constructions to reveal that prototypically Bamanan syntax is second-order indexical (Silverstein 2003) of "church-speak, formality and heaviness". These findings suggest that these so-called Bamanan forms are enregistered (Agha 2007b) for a certain social domain as sociolinguistic high-forms that are used to defer authentically or in a tropic manner to other persons in semiotic encounters.

\section{Glosses and Abbreviations}

\begin{tabular}{|l|l|l|l|}
\hline ART & tonal article & FOC & focalization marker \\
\hline 3SG & third person singular pronoun & IPVF.AFF & imperfective affirmative auxiliary \\
\hline 1SG & first person singular pronoun & PFV.NEG & perfective negative auxiliary \\
\hline 2SG & second person singular pronoun & PFV.AFF & perfective affirmative auxiliary \\
\hline BF & Burkina Faso & REFL & reflexive pronoun \\
\hline BFJ & Burkina Faso Jula & RV & reflexive verb \\
\hline EMPH & emphatic & REL & relative marker \\
\hline
\end{tabular}

\section{BIBLIOGRAPHY}

AGHA Asif, 2007a, “The object called 'Language' and the subject of linguistics”, Journal of English Linguistics 35(3), pp. 217-235.

AGHA Asif, 2007b, Language and Social Relations, New York, Cambridge University Press.

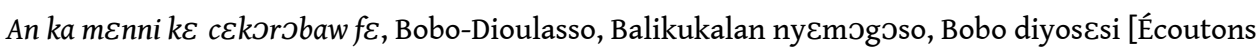
les aînés, Bobo-Dioulasso, Direction de l'alphabétisation, Diocèse de Bobo-Dioulasso]. 
BAZIN Jean, 1985, « À chacun son bambara », in AMSELLE Jean-Loup \& M’BoKOLo Elikia (éd.), Au cœur de l'ethnie : ethnies, tribalisme et État en Afrique, Paris, La Découverte, p. 87-127.

BLOMMAERT Jan, 2013, "From fieldnotes to grammar: Artefactual ideologies of language and the micro-methodology of linguistics", Tilburg Papers in Cultural Studies, no 84.

BRACONNIER Cassian, MAIRE John \& TERA Kalilou, 1983, Études sur le mandingue de Côte d'Ivoire, Paris-Abidjan, Agence de coopération culturelle et technique.

CANUT Cécile, 2002, «Langues et filiations en Afrique », Les Temps Modernes, $\mathrm{n}^{\circ}$ 620-621, p. 410-440.

Corpus Bambara de Référence, Corpus Bambara de Référence. URL :http://cormand.humanum.fr/index.html (23 May, 2016b)

CREISSELS Denis, 2007, "A sketch of Bambara argument structure", Workshop Grammar and Processing of Verbal Arguments, Leipzig, 20-21 April, 2017.

CREISSELS Denis, 2009, “Le malinké de Kita : un parler mandingue de l'ouest du Mali”, Mande Langues and Linguistics, no 9, Köln, Rüdiger Köppe Verlag.

DALBY David, 1971, "Introduction: Distribution and Nomenclature of the Manding People and Their Language", in HODGE Carleton (ed.), Papers on the Manding 3(1-13) (African Series), Bloomington (IN), Indiana University Publications.

DUMESTRE Gérard, 1970, Éléments de grammaire dioula, Université d'Abidjan, Institut de Linguistique Appliquée.

DUMESTRE Gérard, 1974, Lexique fondamental du dioula de Côte d'Ivoire, coll. « Documents Linguistiques » 51, Université d'Abidjan, Institut de Linguistique Appliquée.

DUMESTRE Gérard, 2003, Grammaire fondamentale du bambara, Paris, Karthala.

DUMESTRE Gérard \& RETORD G.L.A, 1981, Kó di? : cours de dioula, Université d'Abidjan, Nouvelles éditions africaines.

ERRINGTON Joseph, 2008, Linguistics in a Colonial World: A Story of Language, Meaning, and Power, Malden-Oxford, Blackwell Pub.

FERGUSON Charles, 1959, “Diglossia”, Word 15, pp. 325-340.

FREKKO Susan, 2009, “ 'Normal' in Catalonia: Standard language, enregisterment and the imagination of a national public", Language in Society 38(1), pp. 71-93.

HYMES Dell, 1974, "Ways of speaking”, in BAUMAN Richard \& SHERZER Joel (ed.), Explorations in the ethnography of speaking, pp. 433-451.

IRVINE Judith T. \& GAL Susan, 2000, "Language Ideology and Linguistic Differentiation”, in KROSKRITY Paul (ed.), Regimes of Language: Ideologies, Polities, and Identities, Santa Fe (NM), School of American Research Press, pp. 35-84.

IRVINE Judith T., 2008, “Subjected words: African linguistics and the colonial encounter", Language \& Communication 28(4), pp. 323-343. DOI :10.1016/j.langcom.2008.02.001.

KEITA Alou, 1990, Esquisse d'une analyse ethno-sémiologique du Jula vernacularisé de Bobo-Dioulasso, Université de Nice, Thèse pour le doctorat nouveau régime.

KONATÉ Moussa, 2010, Bibata et les génies des collines, Bibata ni Jinamuso, dioula-français, $2^{\text {nd }}$ ed.

KONÉ Dramane, 1984, Le verbe bambara : essai sur les propriétés syntaxiques et sémantiques, Grenoble, Université de Grenoble. 
LEVTZION Nehemia, 1973, Ancient Ghana and Mali, London, Methuen.

Lexique, 1995, Lexique de base provisoire : Jula. Burkina Faso, Ministère de l'Enseignement de Base et de l'Alphabétisation, Direction Générale de l'Institut de l'Alphabétisation.

LUCY John A, 1993, "Reflexive language and the human disciplines", in LUCY John A (ed.), Reflexive Language: Reported Speech and Metapragmatics, Cambridge, Cambridge University Press, pp. 9-32.

MANSOUR Gerda, 1993, “The Spread of the Manding Language and the Emergence of Vertical Multilingualism”, Multilingualism and Nation Building, vol. 91, Clevedon, England; Buffalo, NY, Multilingual Matters, pp. 26-44.

MCINTOSH Janet, 2010, “Mobile Phones and Mipoho's Prophecy: The Powers and Dangers of Flying Language", American Ethnologist 37(2), pp. 337-353.

MCLAUGHLIN Fiona, 2001, "Dakar Wolof and the Configuration of an Urban Identity", Journal of African Cultural Studies 14(2), pp. 153-172.

MERTZ Elizabeth, 1985, "Beyond Symbolic Anthropology: Introducing Semiotic Mediation”, in MERTZ Elizabeth \& PARMENTIER Richard J. (eds.), Semiotic Mediation: Sociocultural and Psychological Perspectives, Waltham (MA), Academic Press, pp. 1-19.

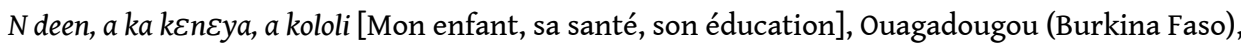
Institut national de l'alphabétisation, coll. « Post-Alpha Femme », 1998.

PARTMANN Gayle, 1973, Le dioula véhiculaire en Côte d'Ivoire :étude comparative des jeunes locuteurs primaires et secondaires du dioula, Stanford University, Thesis Dissertation.

PARTMANN Gayle, 1974, "Derivation and simplification by adolescent Dioula speakers", Studies in African Linguistics 5(1), pp. 101-115.

PEIRCE Charles S., 1992, The Essential Peirce: Selected Philosophical Writings, Volume 1 (1867-1893), HOUSER Nathan \& KLOESEL Christian J. W (eds.), Bloomington, Indiana University Press.

PRATT Mary Louise, 1987, “Linguistic Utopias”, in MACCABE Colin, FABB Nigel, ATTRIDGE Derek, DURANT Alan (eds.), The Linguistics of Writing: Arguments Between Language and Literature, Manchester, Manchester University Press, pp. 48-66.

RYMES Betsy, 2014, "Marking Communicative Repertoire Through Metacommentary", in BLACKLEDGE Adrian \& CREESE Angela (eds.), Heteroglossia as Practice and Pedagogy, Heidelberg, Springer, pp. 301-316.

SANGARÉ Aby, 1984, Dioula de Kong (Côte d'Ivoire) : phonologie, grammaire, lexique et textes, Grenoble, Université de Grenoble 3, Thèse de $3^{\mathrm{e}}$ cycle.

SANOGO Lamine, 2013, « De l'identité bobolaise : le rôle du dioula véhiculaire », in WERTHMANN Katja \& SANOGO Lamine (eds.), La ville de Bobo-Dioulasso au Burkina Faso : urbanité et appartenances en Afrique de l'Ouest, Paris, Karthala, p. 259-278.

SANOGO Mamadou Lamine, 2003, «L'ethnisme jula : origines et évolution d'un groupe ethnolinguistique dans la boucle du Niger », in YÉNOUYABA Georges Madiéga \& NAO Oumarou (ed.), Burkina Faso : Cent ans d'histoire, 1895-1995, Tome 1, Paris, Karthala, pp. 369-379.

SAUSSURE Ferdinand de, 1972, Cours de linguistique générale, Paris, Payot.

SILVERSTEIN Michael, 1976, "Shifters, Linguistic Categories, and Cultural Description”, in BASSO Keith H \& SELBY Henry (eds.), Meaning in Anthropology, Santa Fe (NM), University of New Mexico Press, pp. 11-55. 
SILVERSTEIN Michael, 2003, "Indexical Order and the Dialectics of Sociolinguistic life", Language \& Communication 23(3-4), pp. 193-229. DOI :10.1016/S0271-5309(03)00013-2.

SIMONIS Francis, 2010, L'Afrique soudanaise au Moyen Âge : le temps des grands empires (Ghana, Mali, Songhai), Marseille, Scérén-CRDP de l'académie d'Aix-Marseille.

SPITULNIK Debra, 1998, “The Language of the City: Town Bemba as Urban Hybridity”, Journal of Linguistic Anthropology 8(1), pp. 30-59.

TRAORÉ Mariam Elisabeth, 1998, Nsiirin ni Maana, Ouagadougou (Burkina Faso), Imprimerie de la D.G.I.NA.

VAN DEN AVENNE Cécile, 2005, « Bambara et français-tirailleur. Une analyse de la politique linguistique au sein de l'armée coloniale française : la Grande Guerre et après ", Documents pour l'Histoire du Français Langue Étrangère ou Seconde, $\mathrm{n}^{\circ}$ 35, p. 123-150.

VAN DEN AVENNE Cécile, 2015a, "Reducing languages to writing: the politics of transcription in early colonial French Bamanan handbooks", in ZIMMERMANN Klaus \& KELLERMEIER-REHBEIN Birte (eds.), Colonialism and Missionary Linguistics, Berlin-Boston, De Gruyter.

VAN DEN AVENNE Cécile, 2015b, « Des pratiques de terrain aux descriptions linguistiques : la constitution d'un savoir scientifique sur les langues africaines. Le cas des langues mandingues ", in ESPAGNE Michel \& LÜSEBRINK Hans-Jürgen (eds.), Transferts de savoirs sur l'Afrique, Paris, Karthala, p. 203-226.

VYDRINE Valentin, 1994, «Verbes réfléchis bambara. Première partie : Pronoms réfléchis. Groupement sémantico-syntaxiques des verbes non-réfléchis ", Mandenkan, n 28, p. 1-91. VYDRINE Valentin, 1995a, “Who speaks 'Mandekan'? : A note on Current Use of Mande Ethnonyms and Linguonyms", MANSA Newsletter 25, pp. 6-9.

VYDRINE Valentin, 1995b, « Verbes réfléchis bambara. Deuxième partie : Classification des verbes réfléchis », Mandenkan, $n^{\circ}$ 29, p. 1-114.

VYDRIN Valentin, 2011, Cours de grammaire bambara, ms.

WHORF Benjamin Lee, 1956, Language, Thought, and Reality: Selected Writings of Benjamin Lee Whorf, Cambridge, MIT Press.

WILKS Ivor, 1968, “The transmission of Islamic learning in the western Sudan”, in GOODY Jack (ed.), Literacy in Traditional Societies, Cambridge, Cambridge University Press, pp. 162-197.

WILKS Ivor, 2000, "The Juula and the expansion of Islam into the forest", in LEVTZION Nehema \& POUWELs Randall L. (eds.), The History of Islam in Africa, Athens (OH), Ohio University Press, pp. 93-115.

WORTHAM Stanton, 2001, Narratives in Action: A Strategy for Research and Analysis, New York, Teachers College Press.

\section{NOTES}

1. Herein I refer to written texts as ARTIFACTS in the tradition of the three major kinds of data typically collected through ethnography: participant observation, interviews and artifacts.

2. For the purposes of this paper, I will use a Latin-based orthography for my analysis. I follow the de facto official phonemic orthography synthesizing the various national standards that linguists use while also marking tone. Grave diacritics mark low tones and acute diacritics mark 
high tones. An unmarked vowel carries the same tone as the last marked vowel before it. The tonal article on nouns is noted by an apostrophe but not in citation form.

3. Bambara, Malinké and Dioula are the French names and spellings of Bamanan, Maninka and Jula respectively.

4. With the notable exception of third person plural $\breve{u}$ which in certain rare cases also takes $\hat{i}$ as the reflexive pronoun, albeit with a semantic nuance (Vydrin 2011).

5. Note that as is often conventional in spoken English I will use the gender neutral reflexive pronoun themself for gender ambiguous singular antecedents (e.g., "agent").

6. Note that the vowel of lon is not lengthened in the quote from (9); it is related to a Burkina Faso orthographic convention for monosyllabic words in Jula.

7. One anonymous reviewer for instance suggested that the idiomatic transitive form kà jí kò was an Ivoirian marker though they also added it was "tagbusi".

8. Also referred to as gouin.

9. Note that I have preserved the spelling utilized within the document for the excerpts.

10. [ : overlap

( : unclear

\section{ABSTRACTS}

This article explores one structural way in which Jula differs from other Manding varieties: the forgoing of formally reflexive constructions in favor of formally ambiguous intransitive constructions and more rarely innovative idiomatic transitive constructions. To do so, I draw on contextually elicited forms from 2012 fieldwork with 9 Jula speakers in Burkina Faso. Given the limitations of elicitation, I explore wider acceptability judgments and text artifacts to reveal that Jula speakers in Burkina frequently recognize and in fact use formally reflexive constructions typically attributed to other Manding varieties such as Bamanan. These findings suggest that these so-called Bamanan constructions are enregistered (Agha 2007) for a certain social domain as sociolinguistic high-forms. This study thereby reveals the limitations of a traditional dialectology approach to understanding how various Manding forms circulate across isomorphic boundaries.

Cet article est une enquête sur un trait formel qui distingue le dioula des autres variétés mandingues: l'abandon de constructions formellement réfléchies en faveur des constructions intransitives formellement ambiguës et plus rarement des constructions transitives idiomatiques innovatrices. À ce titre, je me focalise sur des formes contextuellement sollicitées en 2012 pendant une période de recherche au Burkina Faso avec 9 locuteurs du dioula. Étant donné les limites de la sollicitation linguistique des formes, je m'appuie aussi sur des jugements d'acceptabilité ainsi que des textes afin de révéler que souvent les locuteurs du dioula du Burkina Faso reconnaissent et même se servent des constructions formellement réfléchies qui sont le plus souvent considérées comme étant des formes bambara. Ces données suggèrent que ces soi-disant constructions bambara font partie d'un registre sociolinguistique valorisé pour un domaine social particulier. Cette enquête révèle ainsi les limites d'une approche purement dialectologique vu que des formes mandingues peuvent circuler au-delà des frontières isomorphiques. 
В СТАТЬЕ АНАЛИЗИРУЕТСЯ ОДНА СТРУКТУРНАЯ ЧЕРТА, ПО КОТОРОЙ ДЬЮЛА ОТЛИЧАЕТСЯ ОТ ДРУГИХ ИДИОМОВ МАНДЕН: В НЁМ ОКАЗЫВАЮТСЯ МАЛОУПОТРЕБИТЕЛЬНЫМИ ФОРМАЛЬНОРЕФЛЕКСИВНЫЕ КОНСТРУКЦИИ, ВМЕСТО КОТОРЫХ ИСПОЛЬЗУЮТСЯ ФОРМАЛЬНО ДВУСМЫСЛЕННЫЕ НЕПЕРЕХОДНЫЕ КОНСТРУКЦИИ ИЛИ, РЕЖЕ, ИННОВАТИВНЫЕ ИДИОМАТИЧЕСКИЕ ПЕРЕХОДНЫЕ КОНСТРУКЦИИ. ИСХОДНОЙ ТОЧКОЙ ИССЛЕДОВАНИЯ СТАЛИ

ДАННЫЕ ПРЯМОГО ОПРОСА 9 НОСИТЕЛЕЙ ДЬЮЛА БУРКИНА ФАСО, ПРОВЕДЁННЫЕ В ХОДЕ ЭКСПЕДИЦИИ 2012 ГОДА. ПОСКОЛЬКУ ЭТИ ДАННЫЕ НОСЯТ ОГРАНИЧЕННЫЙ ХАРАКТЕР, Я ПРИНЯЛ ВО ВНИМАНИЕ И ДРУГИЕ СУЖДЕНИЯ О ПРИЕМЛЕМОСТИ КОНСТРУКЦИЙ, А ТАКЖЕ ТЕКСТЫ НА ДЬЮЛА. ЭТО ПОКАЗАЛО, ЧТО ГОВОРЯЩИЕ НА БУРКИНИЙСКОМ ДЬЮЛА ЧАСТО УЗНАЮТ И ДАЖЕ ИСПОЛЬЗУЮТ ФОРМАЛЬНО-РЕФЛЕКСИВНЫЕ КОНСТРУКЦИИ, КОТОРЫЕ В ТИПИЧНОМ СЛУЧАЕ СЧИТАЮТСЯ ОСОБЕННОСТЬЮ ДРУГИХ ИДИОМОВ МАНДЕН, ТАКИХ КАК БАМАНА. ЭТИ НАБЛЮДЕНИЯ ПОЗВОЛЯЮТ ПРЕДПОЛАГАТЬ, ЧТО Т. Н. «БАМАНСКИЕ КОНСТРУКЦИИ» ХАРАКТЕРНЫ

ДЛЯ НЕКОЕГО СОЦИОЛИНГВИСТИЧЕСКОГО ВЫСОКОГО РЕГИСТРА. ДАННОЕ ИССЛЕДОВАНИЕ ДЕМОНСТРИРУЕТ ОГРАНИЧЕННОСТЬ ТРАДИЦИОННОГО ДИАЛЕКТОЛОГИЧЕСКОГО ПОДХОДА ДЛЯ ПОНИМАНИЯ ТОГО, КАК РАЗЛИЧНЫЕ МАНДИНГСКИЕ ФОРМЫ ЦИРКУЛИРУЮТ ПОВЕРХ ГРАНИЦ

идиомов.

INDEX

Mots-clés: dioula, Burkina Faso, dialecte, registre, verbe réfléchi

motsclesru ДЬЮЛА, БУРКИНА ФАСО, ДИАЛЕКТ, РЕГИСТР, РЕФЛЕКСИВНЫЕ ГЛАГОЛЫ

Keywords: Jula, Burkina Faso, dialect, register, reflexive verbs

\section{AUTHOR}

\section{COLEMAN DONALDSON}

University of Pennsylvania

coleman.donaldson@gmail.com 